\title{
Arbuscular Mycorrhizal Fungi, Organic and Inorganic Controlled-release Fertilizers: Effect on Growth and Leachate of Container-grown Bush Morning Glory (Ipomoea carnea ssp. fistulosa) Under High Production Temperatures
}

\author{
Lucila Amaya Carpio, Fred T. Davies, Jr. ${ }^{1}$, and Michael A. Arnold \\ Department of Horticultural Sciences, Texas A\&M University, College Station, TX 77843-2133
}

ADDITIONAL INDEX WORDS. mycorrhiza, colonization, organic slow release fertilizer, inorganic controlled-release fertilizer, plant growth, best management practices, nutrition

\begin{abstract}
This research determined the effects of two commercial arbuscular mycorrhizal fungi (AMF) inocula, organic slow-release fertilizer (OSRF), and inorganic controlled-release fertilizer (ICRF) on plant growth, marketability and leachate of container-grown Ipomoea carnea N. von Jacquin ssp. fistulosa (K. Von Martinus ex J. Choisy) D. Austin (bush morning glory) grown outdoors under high temperature summer conditions (maximum container media temperature averaged $44.8^{\circ} \mathrm{C}$ ). Uniform rooted liners were planted into 7.6-L pots containing a pasteurized substrate [pine bark and sand (3:1, by volume)]. The AMF treatment consisted of BioterraPLUS and MycorisePro and a noninoculated control (NonAMF). Fertilizer treatments included OSRF [Nitrell 5-3-4 (5N-1.3P-3.3K)] and ICRF [Osmocote 18-7-10 (18N-3.0P-8.3K)]. OSRF was tested at three rates: $8.3,11.9$, and $16.6 \mathrm{~kg} \cdot \mathrm{m}^{-3}$, which were respectively, $70 \%$, $100 \%$, and $140 \%$ of manufacturer's recommended rate, while ICRF was tested at two rates: 3.6 and $7.1 \mathrm{~kg} \cdot \mathrm{m}^{-3}$, which were, respectively, $50 \%$ and $\mathbf{1 0 0 \%}$ of manufacturer's recommended rate. The $P$ levels were equivalent between $70 \%$ and $140 \%$ OSRF and, respectively, 50\% and 100\% ICRF. Greatest growth [leaf, shoot, flower bud, and flower number; root, leaf, shoot, and total plant dry mass (DM); growth index; leaf area]; N, P, and K uptake; leaf chlorophyll; and plant marketability occurred with BioterraPLUS plants at 50\% and 100\% ICRF rate and MycorisePro at the $100 \%$ ICRF rate. Greater plant growth occurred with increasing fertility levels; however, plants at the 140\% OSRF (same P level as $\mathbf{1 0 0 \%}$ inorganic SRF) had poorest growth, in part due to high temperature. While AMF enhanced growth of plants with OSRF at all concentrations, better growth and marketability occurred with ICRF than OSRF plants inoculated with AMF. AMF plants at the $50 \%$ ICRF had comparable or better growth, higher N, P, and K and marketability than NonAMF plants at either $100 \%$ OSRF or ICRF. AMF were able to survive under high temperature and colonize plants grown from low to high fertility conditions. AMF inoculation had minimal effect on container leachate ( $\mathrm{pH}$ and electrical conductivity). However, the larger-sized AMF plants at $100 \%$ ICRF rate had greater total leaf tissue N, $\mathbf{P}$, and $\mathrm{K}$, suggesting greater nutrient utilization - thus reduced potential risk for leachate runoff.
\end{abstract}

Increased environmental concerns have resulted in state and governmental regulations that affect water and land use. These regulations are impacting the nursery and greenhouse industries (Lee-Cox and Ross, 2001). To comply with these environmental regulations the nursery and greenhouse industries have developed best management practices (BMPs), such as more efficient fertilization systems, including inorganic controlled-release (ICRF) and organic slow-release fertilizer (OSRF) usage, incorporating biological pest control management, reducing irrigation water volume and subsequent nutrient leaching, and capturing and treating water runoff (Davies et al., 2000; Yeager et al., 1997). Hence, one of the most important challenges facing the nursery and greenhouse industries is the creation and incorporation of practices into production systems that reduce pesticide and fertil-

Received for publication 6 Feb. 2004. Accepted for publication 17 Apr. 2004. This study was supported in part by the Texas Agricultural Experiment Station, Premier Tech, Rivière-du-Loup, Québec, Canada and the USDA-National Research Initiative for Floriculture and Nursery Research, grant\# 58-6204-0.106. We thank Premier Tech and Bioterra Technologies (Las Vegas, Nev.) for supplying commercial AMF inoculum. We thank Robert G. Linderman for critical review of the manuscript. We thank Garry McDonald and Andy Cartmill for their technical expertise and assistance.

${ }^{1}$ To whom reprint requests should be addressed. Tel. 979-845-4524; Fax 979845-0627; E-mail: f-davies@tamu.edu izer usage, without reducing plant quality and marketability.

Beneficial microorganisms include arbuscular mycorrhizal fungi (AMF), which are able to colonize and establish symbiotic (mutually beneficial) associations with roots of most nursery crops (Davies, 2000; Linderman, 1986). AMF increase the effective absorptive area of roots by formation of an extensive extraradical hypha network that enhances efficiency in absorption of nutrients (George, 2000). Plants colonized by AMF can have better growth responses, improved water relations, greater tolerance to environmental stresses, and better transplant survival when compared to similar noncolonized (NonAMF) plants (Augé, 2001; Biermannn and Linderman, 1983; Davies et al., 1992, 1993; Linderman, 1986; Sylvia et al., 1998; Varma and Schuepp, 1996).

Biermann and Linderman (1983) reported enhanced shoot DM and $\mathrm{P}$ accumulation of Pelargonium $\times$ hortorum L.H. Bail. (geranium) colonized by Glomus fasciculatum (Thaxter) Gerdemann $\&$ Trappe emend. Walker and Koske when grown at low P levels $\left(11 \mu \mathrm{g} \cdot \mathrm{mL}^{-1}\right)$. Growth of Nandina domestica Thunb., Loropetalum chinense (R. Br.) Oliv., and Salvia gregii A. Gray. was enhanced when colonized by Glomus intraradices Schenck \& Smith under a commercial nursery production system (Davies et al., 2000). In the latter study, G. intraradices were able to survive, establish colonization, and increase plant growth even at high fertility levels common in commercial nursery production systems. 
High container temperature is a frequent summer problem in Texas and southern U.S. nursery production systems. AMF can partially alleviate plant stress under high container temperatures (Newman and Davies, 1988a, 1988b). Temperature is also one of the critical factors affecting the release of nutrients from resincoated ICRF, which have $60 \%$ greater release at $38{ }^{\circ} \mathrm{C}$ than 20 ${ }^{\circ} \mathrm{C}$ (Cabrera, 1997). Likewise, temperature indirectly controls release of OSRF by affecting fungal and bacterial microbial activity (Cabrera, 1997).

This research investigated the role of selected commercial AMF inoculum in the growth and nutrient uptake of OSRF and ICRF in nursery container-produced Ipomoea carnea ssp. fistulosa. OSRF are becoming more prevalent because of developing market niches for organic nurseries, and greater organic waste byproduct availability leading to development of markets for their utilization. We hypothesized that AMF would increase the efficacy of OSRF and ICRF, therefore improving growth and marketability of containerized nursery plants exposed to high temperatures during summer production. AMF enhancement in utilization efficiency of OSRF and ICRF could potentially allow the use of lower fertilizer rates and minimize nutrient content in leachates from containers - while still producing marketable ornamental container crops.

Hence, the objectives of this study were: 1) to evaluate effectiveness of selected commercial AMF inocula on the growth and marketability of container produced $I$. carnea at different levels of OSRF and ICRF, and 2) to determine the effectiveness of different commercial AMF inoculum on leachate $\mathrm{pH}$ and electrical conductivity (EC) under high temperature conditions in the container production of I. carnea at different levels of OSRF and ICRF.

\section{Materials and Methods}

Plant growth conditions. The study was conducted under a simulated commercial container production system from 3 July to 30 Aug. 2000, at the Texas A\&M Univ. (TAMU) Nursery Crop Production facility, College Station. Plant propagation material was taken from stock plants of Ipomoea carnea ssp. fistulosa (bush morning glory) grown at the TAMU Horticultural Gardens. Single three-node cuttings without auxin application were rooted and grown in perlite substrate under intermittent mist until of sufficient size for transplanting. Uniform, rooted plants were transplanted into 7.6-L (2 gal) pots containing steam-pasteurized $\left(65^{\circ} \mathrm{C}\right.$ for $4 \mathrm{~h}$ over 2 consecutive days) soilless substrate ( 3 pine bark : 1 sand $\mathrm{v} / \mathrm{v})$. After pasteurization, the substrate was amended with Micromax trace elements (Sierra Chemical Co., Mipitas, Calif.) $0.9 \mathrm{~kg} \cdot \mathrm{m}^{-3}$, dolomitic limestone at $3.5 \mathrm{~kg} \cdot \mathrm{m}^{-3}$, and gypsum $\left(\mathrm{CaSO}_{4}\right)$ at $1.75 \mathrm{~kg} \cdot \mathrm{m}^{-3}$.

Two selected commercial arbuscular mycorrhizal fungi (AMF) inocula, BioterraPLUS (BioTerra Technologies, Las Vegas) and MycorisePro (Premier Tech, Quebec) were placed into the same dibble hole as the rooted cuttings of I. carnea during transplanting into containers. Cuttings of I. carnea without AMF inoculum served as the noninoculated controls (NonAMF). Inoculum of BioterraPLUS is a composite mix of seven mycorrhizal fungal species. These species include: Gigaspora rosea Nicolsen et Schenck, Glomus deserticola Trappe, Bloss \& Menge, Glomus intraradices Schenck \& Smith, Glomus mosseae (Nicolson \& Gerderman) Gerderman and Trappe, Glomus etunicatum Becker \& Gerdemann, Glomus monosporus Gerdemann \& Trappe, and Glomus brasilianum Spain and Miranda (Paraglomus brasilia- num. Morton and Redecker). The commercially recommended rate of application is $30 \mathrm{~mL}$ per 7.6-L container. The inoculation rate for this experiment was $2 \times(60 \mathrm{~mL})$ the recommended rate. MycorisePro inoculum is a single isolate of Glomus intraradices. The commercially recommended rate of application is $60 \mathrm{~mL}$ per 7.6-L container. Inoculation rate for the experiment was $1.5 \times(90$ $\mathrm{mL})$ the recommended rate.

Fertilizer treatments included OSRF (Nitrell, Fertrell Co; Bainbridge, Pa.) and ICRF (Osmocote; Scotts Co., Marysville, Ohio) (Table 1). Nitrell 5-3-4 (5N-1.3P-3.3K) was evaluated at three levels: $8.3 \mathrm{~kg} \cdot \mathrm{m}^{-3}\left(14 \mathrm{lb} / \mathrm{yard}^{3}\right), 11.9 \mathrm{~kg} \cdot \mathrm{m}^{-3}\left(20 \mathrm{lb} / \mathrm{yard}^{3}\right)$, and $16.6 \mathrm{~kg} \cdot \mathrm{m}^{-3}\left(28 \mathrm{lb} / \mathrm{yard}^{3}\right)$, which were respectively, $70 \%$, $100 \%$, and $140 \%$ of the commercially recommended application rate (Table 1). Osmocote $18-7-10(18 \mathrm{~N}-3.0 \mathrm{P}-8.3 \mathrm{~K})$ was tested at two levels: $3.6 \mathrm{~kg} \cdot \mathrm{m}^{-3}\left(6 \mathrm{lb} / \mathrm{yard}^{3}\right)$ and $7.1 \mathrm{~kg} \cdot \mathrm{m}^{-3}\left(12 \mathrm{lb} / \mathrm{yard}^{3}\right)$, which were $50 \%$ and $100 \%$, respectively, of the recommended rate. Since $\mathrm{P}$ is the most important fertilizer element in establishing mycorrhizal associations (Smith and Read, 1997), it was important to equilibrate P levels between the OSRF and ICRF sources. The $\mathrm{P}$ levels were equivalent between $70 \%$ and 140\% OSRF and, respectively, 50\% and 100\% ICRF. Fertilizers were top-dressed (broadcast) within each container, and covered with a 1-cm layer of pasteurized medium to avoid loss of product. All plants were irrigated via $6.7 \mathrm{~cm}(2-5 / 8$ inches $)$ Spot Spitter $160^{\circ}$ spray pattern at $0.27 \mathrm{~L} \cdot \mathrm{min}^{-1}$ (Roberts Irrigation Products, San Marcos, Calif.). The irrigation water was to be adjusted from a normal $\mathrm{pH} 8.0$ to a lower $\mathrm{pH} 6.5$ via injection of sulfuric acid. The experiment was conducted for $58 \mathrm{~d}$ (from 3 July to 30 Aug. 2000).

Average daily maximum air temperature from 3 July to 30 Aug. 2000 was $39.2^{\circ} \mathrm{C}$ during container nursery production. Air temperature was measured with a WatchDog Data logger (model \#150; Spectrum Technologies, Plainfield, Ill.). Portable temperature probes (model \#909000, TempTester; Cole Palmer, Vernon Hills, Ill.) were used to measure container rootball temperatures. The probes were vertically inserted $10 \mathrm{~cm}$ into the center of containers. There were no significant differences in container root zone temperatures among mycorrhizal (AMF), fertility sources, and concentrations, nor were there any interactions. Root ball temperatures were measured on days 28, 38, and 45 of the experiment with an average maximum root ball temperature of $44.8^{\circ} \mathrm{C}(\mathrm{n}=10)$. Maximum air temperature during the same period was $38.7^{\circ} \mathrm{C}$.

Plant growth measurements. At termination of the experiment, plant growth index was calculated by the formula (height $x$ diameter $_{1} \times$ diameter $_{2}$ ). Diameter $_{2}$ was measured perpendicular to diameter $_{1}$ (Arnold and Lang, 1996). At harvest, leaf surface area, shoot and root DM, and root : shoot ratio were also determined (n $=15$ ). Number of leaves, stems (number of basal branches derived from the main stem), flower buds (not opened), and bloom numbers (flowers at anthesis) was also recorded $(n=15)$. Leaf area was determined with a LI-COR leaf area meter, model LI-3000A (LI-COR, Lincoln, Nebr.). Mycorrhizal inoculation effect (MIE) was determined by MIE $(\%)=(\mathrm{DM}$ of AMF plant at comparable fertility - DM of NonAMF plant at comparable fertility $) \times 100 \times$ (DM noninoculated plant) $)^{-1}$ (Bagyaraj et al., 1988).

LEAF CHLOROPHYLL CONTENT AND LEAF TISSUE ANALYSIS. Measurement of total leaf chlorophyll (CHL $a+b)$ was determined with a nondestructive method (Yadava, 1986) using a portable chlorophyll meter (SPAD-502; Minolta Camera Co., Osaka, Japan). The SPAD-502 meter readings $(n=15$ plants per treatment $)$ were correlated with a chlorophyll content prediction equation: $\mathrm{y}=-8.53+1.96 \mathrm{x} ; \mathrm{y}=$ chlorophyll content $\left(\mu \mathrm{g} \cdot \mathrm{cm}^{-2}\right), \mathrm{x}=$ chlo- 
Table 1. Comparison of organic slow release (OSRF) and inorganic controlled release fertilizer (ICRF) used in container study of Ipomoea carnea.

\begin{tabular}{|c|c|c|c|c|c|}
\hline $\begin{array}{l}\text { Fertilizer } \\
\text { type }\end{array}$ & Formulation & $\begin{array}{c}\text { Proportion of } \\
\text { manufacturer's } \\
\text { recommended rate } \\
(\%)\end{array}$ & $\begin{array}{c}\text { Recommended } \\
\text { rate } \\
{\left[\mathrm{kg} \cdot \mathrm{m}^{-3}\left(16 / \mathrm{yard}^{3}\right)\right]}\end{array}$ & $\begin{array}{c}\text { Total }^{\mathrm{z}} \\
\mathrm{N}-\mathrm{P}-\mathrm{K} \\
\left(\mathrm{kg} \cdot \mathrm{m}^{-3}\right)\end{array}$ & $\begin{array}{l}\text { Cost } \\
\left(\$ / \mathrm{m}^{3}\right)\end{array}$ \\
\hline OSRF & $\begin{array}{c}\text { Nitrell 5-3-4 } \\
(5 \mathrm{~N}-1.3 \mathrm{P}-3.3 \mathrm{~K})\end{array}$ & 70 & $\begin{array}{c}8.3 \\
(14)\end{array}$ & $0.4-0.1-0.3$ & 6.78 \\
\hline \multirow{2}{*}{$\begin{array}{l}\text { Sources } \\
\text { Bone meal, } \\
\text { cocoa meal, fish meal, } \\
\text { peanut meal, feather } \\
\text { meal, chicken manure, } \\
\text { sulfate of potash, } \\
\text { aragonite, rock } \\
\text { phosphate }\end{array}$} & & 100 & $\begin{array}{l}11.9 \\
(20)\end{array}$ & $0.6-0.2-0.4$ & 9.70 \\
\hline & & 140 & $\begin{array}{l}16.6 \\
(28)\end{array}$ & $0.8-0.2-0.6$ & 13.58 \\
\hline ICRF & $\begin{array}{c}\text { Osmocote } 18-7-10 \\
(18 \mathrm{~N}-3 \mathrm{P}-8.3 \mathrm{~K})\end{array}$ & 50 & $\begin{array}{l}3.6 \\
(6)\end{array}$ & $0.6-0.1-0.3$ & 8.21 \\
\hline $\begin{array}{l}\text { Sources } \\
\text { Ammonium nitrate } \\
\text { Ammonium phosphate } \\
\text { Calcium phosphate } \\
\text { Potassium sulfate }\end{array}$ & & 100 & $\begin{array}{c}7.1 \\
(12)\end{array}$ & $1.3-0.2-0.6$ & 16.43 \\
\hline
\end{tabular}

${ }^{z}$ Total $\mathrm{N}-\mathrm{P}-\mathrm{K}=($ Formulation $) \times\left(\mathrm{kg} \cdot \mathrm{m}^{-3}\right)$; i.e., $[5-3-4] \times\left(8.3 \mathrm{~kg} \cdot \mathrm{m}^{-3}\right)=0.4 \mathrm{~N}-0.1 \mathrm{P}-0.3 \mathrm{~K}$.

rophyll meter SPAD-502 reading $\left(r^{2}=0.85\right)$. The equation was obtained by calculating a linear regression analysis between the SPAD-502 readings obtained at day 30 from the youngest pair of fully matured leaves of four different container-grown plants of $I$. carnea and the total chlorophyll content of the same pair of leaves. Leaf chlorophyll was extracted using $N, N$-dimethylformamide and then spectrophotometric measurements were made at $664 \mathrm{~nm}$ and $647 \mathrm{~nm}$ with a Spectronic 21 UVD spectrophotometer (Baush and Lomb, Rochester, N.Y.). Total chlorophyll content (Ct) was calculated by the formula described by Moran (1982); $\mathrm{Ct}=7.04$ $\mathrm{A}_{664}+20.27 \mathrm{~A}_{647}$, where $\mathrm{A}$ is the absorbance at $664 \mathrm{~nm}$ and 647 $\mathrm{nm}$. Leaf chlorophyll readings were determined on day 56.

Leaf elemental tissue analysis was conducted on an inductively coupled plasma atomic emission spectrophotometer (J.R. Peters/Scott's Testing Laboratory, Allentown, Pa.) using a pool of five plants per replicate $(n=3)$ to determine the mineral status of leaf tissue at the termination of the experiment.

Marketability. At day 56, three nursery production professionals evaluated the marketability of the container-grown $I$. carnea $(\mathrm{n}=15$ plants per treatment). The selection criteria were based on standard commercial size, characteristic growth habit, form, bloom characteristics, overall plant quality, and subsequent salability. Marketable plants had compact growth, dark green leaf color, good branching, and the presence of floral buds and flowers at anthesis. Plants that did not meet those criteria were considered nonmarketable (nonsalable). Plants were categorized as either marketable or nonmarketable at the time of evaluation.

Arbuscular mycorrhizal fungi (AMF) colonization. Five plants per treatment were randomly selected and assayed for AMF colonization at the end of the experiment. Five slides of ten $1-\mathrm{cm}$ stained root segments per plant per treatment were examined under a Nikon, Aphaphot YS compound microscope (Nikon, Melville, N.Y.). Three observations (top, middle, and bottom) of each $1-\mathrm{cm}$ root piece at $40 \times$ was evaluated for a total of total of $250(1-\mathrm{cm})$ root segments per treatment (ten $1-\mathrm{cm}$ roots per slide, five slides per plant and five plants per treatment). There were 750 root observations per treatment; $n=5$. Percentage of root length with arbuscules, vesicles, and internal hyphae in root cortical cells were determined, as described by Biermann and Linderman (1981), after clearing and staining the roots with trypan blue according to Koske and Gemma (1989).

Leachateanalysis (PHAND EC). Leachate from the container substrate was monitored in a representative sample (10 containers per treatment) at day 10 and weekly thereafter through day 48 using the pour-through method described by Wright (1986). After collection of the leachate, samples were taken to the laboratory and analyzed the same day for $\mathrm{pH}$ and EC (model 20; pH/conductivity meter, Fisher Accumet; Denver Instrument Co., Arvada, Colo.).

Experimental Design and STATISTICAl Data anAlysis. The experiment was a completely randomized design with a $3 \times 5$ factorial, including three AMF levels (two AMF commercial inocula and a NonAMF control) $\times$ five fertilizer levels (three organic SRF rates and two inorganic SRF rates). Each plant was an experimental unit $(n=15)$. The replication number of other measurements is included in their respective sections of the materials and methods. Data were analyzed using a general linear model (GLM) procedure (SAS Institute, 2000) and the Tukey test $(\alpha=0.05 \%)$ or SE was used to differentiate means.

\section{Results and Discussion}

Plant growth and overall AMF effects. The AMF treatments of BioterraPLUS and MycorisePro enhanced plant growth in combination with both OSRF and ICRF when compared with NonAMF (Tables 2 and 3). There were interactions $(P \leq 0.001)$ between AMF and fertility treatments for root, shoot, leaf, and total plant DM. Greatest growth (leaf, shoot, flower bud, and flower number; root, leaf, shoot and total plant DM; growth index; leaf area); N, P, and K uptake (Table 4); leaf chlorophyll; 
Table 2. Effect of mycorrhizal inoculation [(AMF) BioterraPLUS and MycorisePro], organic slow-release (OSRF) and inorganic controlled-release fertilizers (ICRF) on dry mass (DM) and other growth parameters of container-grown Ipomoea carnea.

\begin{tabular}{|c|c|c|c|c|c|c|c|c|c|c|}
\hline AMF & $\begin{array}{c}\text { Fertility } \\
\text { source }\end{array}$ & $\begin{array}{c}\text { Recommended } \\
\text { level }^{x}\end{array}$ & $\begin{array}{c}\text { Root } \\
\text { DM } \\
(\mathrm{g})\end{array}$ & $\begin{array}{c}\text { Leaf } \\
\text { DM } \\
(\mathrm{g})\end{array}$ & $\begin{array}{c}\text { Shoot } \\
\text { DM } \\
(\mathrm{g})\end{array}$ & $\begin{array}{c}\text { Total plant } \\
\text { DM } \\
(\mathrm{g})\end{array}$ & $\begin{array}{c}\text { Growth } \\
\text { index } \times \\
100^{z} \\
\left(\mathrm{~cm}^{3}\right) \\
\end{array}$ & $\begin{array}{c}\text { Leaf area } \\
\left(\mathrm{cm}^{2}\right)\end{array}$ & $\begin{array}{l}\text { Chlorophyll } \\
\left(\mu \mathrm{g} \cdot \mathrm{cm}^{-1}\right)\end{array}$ & $\begin{array}{c}\mathrm{MIE}^{y} \\
(\%)\end{array}$ \\
\hline \multirow[t]{5}{*}{ NonAMFw } & OSRF & $70 \%$ & $3.4 \pm 0.7^{v}$ & $1.8 \pm 0.3$ & $7.5 \pm 1.6$ & $12.7 \pm 2.3$ & $132 \pm 36$ & $313 \pm 53$ & $51.3 \pm 2.3$ & --- \\
\hline & & $100 \%$ & $4.6 \pm 0.8$ & $2.5 \pm 0.3$ & $8.4 \pm 1.3$ & $15.5 \pm 2.1$ & $162 \pm 31$ & $389 \pm 56$ & $59.9 \pm 2.3$ & --- \\
\hline & & $140 \%$ & $1.2 \pm 0.2$ & $1.0 \pm 0.3$ & $3.0 \pm 0.5$ & $5.2 \pm 0.6$ & $56 \pm 14$ & $121 \pm 33$ & $71.5 \pm 1.5$ & --- \\
\hline & ICRF & $50 \%$ & $2.7 \pm 0.4$ & $1.7 \pm 0.3$ & $6.8 \pm 1.1$ & $11.2 \pm 1.5$ & $132 \pm 23$ & $248 \pm 46$ & $53.0 \pm 1.5$ & --- \\
\hline & & $100 \%$ & $4.0 \pm 0.6$ & $2.8 \pm 0.4$ & $9.7 \pm 1.2$ & $16.5 \pm 1.7$ & $239 \pm 44$ & $452 \pm 68$ & $68.7 \pm 2.3$ & --- \\
\hline \multirow[t]{5}{*}{ BioterraPLUS } & OSRF & $70 \%$ & $5.4 \pm 0.9$ & $2.5 \pm 0.4$ & $11.7 \pm 2.2$ & $19.6 \pm 3.0$ & $204 \pm 44$ & $410 \pm 67$ & $64.5 \pm 3.4$ & 54 \\
\hline & & $100 \%$ & $7.9 \pm 0.9$ & $3.6 \pm 0.2$ & $18.6 \pm 1.6$ & $30.1 \pm 2.4$ & $330 \pm 30$ & $562 \pm 48$ & $65.6 \pm 1.9$ & 94 \\
\hline & & $140 \%$ & $4.1 \pm 1.1$ & $2.2 \pm 0.4$ & $8.3 \pm 1.9$ & $14.6 \pm 3.0$ & $115 \pm 35$ & $328 \pm 59$ & $53.6 \pm 3.4$ & 181 \\
\hline & ICRF & $50 \%$ & $10.5 \pm 1.0$ & $3.9 \pm 0.3$ & $21.4 \pm 1.1$ & $35.8 \pm 1.9$ & $435 \pm 47$ & $673 \pm 59$ & $66.9 \pm 3.2$ & 220 \\
\hline & & $100 \%$ & $12.5 \pm 1.1$ & $5.6 \pm 0.3$ & $26.2 \pm 1.8$ & $44.3 \pm 2.7$ & $609 \pm 62$ & $968 \pm 55$ & $84.2 \pm 2.4$ & 168 \\
\hline \multirow[t]{5}{*}{ MycorisePro } & OSRF & $70 \%$ & $5.0 \pm 0.8$ & $2.6 \pm 0.4$ & $11.5 \pm 2.0$ & $19.1 \pm 2.6$ & $214 \pm 42$ & $426 \pm 59$ & $56.9 \pm 2.5$ & 50 \\
\hline & & $100 \%$ & $5.1 \pm 0.9$ & $5.0 \pm 0.4$ & $10.0 \pm 2.2$ & $20.1 \pm 2.9$ & $148 \pm 46$ & $429 \pm 94$ & $56.3 \pm 1.6$ & 30 \\
\hline & & $140 \%$ & $3.4 \pm 0.7$ & $1.9 \pm 0.3$ & $6.3 \pm 1.1$ & $11.6 \pm 1.9$ & $135 \pm 28$ & $330 \pm 50$ & $61.8 \pm 2.9$ & 123 \\
\hline & ICRF & $50 \%$ & $7.1 \pm 1.0$ & $2.8 \pm 0.3$ & $13.8 \pm 1.5$ & $23.7 \pm 2.4$ & $260 \pm 40$ & $522 \pm 55$ & $64.6 \pm 2.3$ & 112 \\
\hline & & $100 \%$ & $9.9 \pm 1.0$ & $5.0 \pm 0.4$ & $19.7 \pm 1.7$ & $34.6 \pm 2.6$ & $499 \pm 51$ & $894 \pm 48$ & $81.9 \pm 3.5$ & 110 \\
\hline \multicolumn{11}{|l|}{ Significance $(P \leq \mathrm{F})$} \\
\hline AMF & & & $* * *$ & $* * *$ & $* * *$ & $* * *$ & $* * *$ & $* * *$ & $* * *$ & \\
\hline Fertility & & & $* * *$ & $* * *$ & $* *$ & $* * *$ & $* * *$ & $* * *$ & $* * *$ & \\
\hline $\mathrm{AMF} \times$ Fertility & & & $* * *$ & $* *$ & $* * *$ & $* * *$ & $* * *$ & $* *$ & $* * *$ & \\
\hline
\end{tabular}

${ }^{\mathrm{z}}$ Growth index $\times 100=\left(\right.$ height $\times$ diameter $_{1} \times$ diameter $\left._{2}\right)$.

y Mycorrhizal inoculation effect [\% MIE] = (total plant DM of AMF at comparable fertility - DM of NonAMF at comparable fertility level) (DM of NonAMF) $)^{-1} \times 100$

'See Table 1 for explanation of recommended fertility rates and comparative analysis.

wNonAMF $=$ noninoculated control.

values are means \pm SE, $\mathrm{n}=15$.

NS, ${ }^{*}, * * * * *$ Nonsignificant or significant at $P \leq 0.05,0.01$, or 0.001 respectively.

Table 3. Effect of mycorrhizal [(AMF) BioterraPLUS and MycorisePro], organic slow release (OSRF) and inorganic controlled-release fertilizers (ICRF) on number of leaves, shoots, flower buds, flowers, and marketability of container-grown Ipomoea carnea.

\begin{tabular}{|c|c|c|c|c|c|c|c|}
\hline $\mathrm{AMF}$ & $\begin{array}{c}\text { Fertility } \\
\text { source }\end{array}$ & $\begin{array}{c}\text { Recommended } \\
\text { level }^{\mathrm{z}}\end{array}$ & $\begin{array}{l}\text { Leaf } \\
\text { (no.) }\end{array}$ & $\begin{array}{c}\text { Shoot } \\
\text { (no.) }\end{array}$ & $\begin{array}{c}\text { Flower bud } \\
\text { (no.) }\end{array}$ & $\begin{array}{c}\text { Flower } \\
\text { (no.) }\end{array}$ & $\begin{array}{c}\text { Marketability } \\
(\%)\end{array}$ \\
\hline \multirow[t]{3}{*}{ NonAMFy } & OSRF & $70 \%$ & $16.0 \pm 1.4^{x}$ & $1.5 \pm 0.5$ & $0.2 \pm 0.2$ & $1.3 \pm 0.8$ & $20 \pm 11^{w}$ \\
\hline & & $100 \%$ & $17.7 \pm 1.3$ & $1.3 \pm 0.5$ & $0.1 \pm 0.1$ & $0.3 \pm 0.2$ & $20 \pm 11$ \\
\hline & & $140 \%$ & $8.0 \pm 0.8$ & $1.1 \pm 0.3$ & $0.0 \pm 0.0$ & $0.0 \pm 0.0$ & $0 \pm 0$ \\
\hline \multirow[t]{2}{*}{ ICRF } & & $50 \%$ & $17.2 \pm 1.5$ & $1.5 \pm 0.6$ & $0.0 \pm 0.0$ & $0.0 \pm 0.0$ & $13 \pm 9$ \\
\hline & & $100 \%$ & $20.8 \pm 1.6$ & $1.5 \pm 0.6$ & $0.0 \pm 0.0$ & $0.0 \pm 0.0$ & $27 \pm 12$ \\
\hline \multirow[t]{3}{*}{ BioterraPLUS } & OSRF & $70 \%$ & $18.5 \pm 1.7$ & $1.7 \pm 0.7$ & $0.4 \pm 0.3$ & $2.4 \pm 0.9$ & $40 \pm 13$ \\
\hline & & $100 \%$ & $24.3 \pm 1.6$ & $2.1 \pm 1.0$ & $0.4 \pm 0.2$ & $3.5 \pm 1.4$ & $60 \pm 13$ \\
\hline & & $140 \%$ & $15.4 \pm 1.5$ & $1.5 \pm 0.5$ & $0.0 \pm 0.0$ & $0.1 \pm 0.1$ & $13 \pm 9$ \\
\hline \multirow[t]{2}{*}{ ICRF } & & $50 \%$ & $27.7 \pm 2.5$ & $2.2 \pm 0.7$ & $1.7 \pm 0.5$ & $13.9 \pm 2.4$ & $100 \pm 0$ \\
\hline & & $100 \%$ & $36.2 \pm 2.3$ & $2.7 \pm 0.8$ & $3.7 \pm 1.0$ & $28.4 \pm 4.7$ & $100 \pm 0$ \\
\hline \multirow[t]{3}{*}{ MycorisePro } & OSRF & $70 \%$ & $19.6 \pm 2.0$ & $1.4 \pm 0.6$ & $0.0 \pm 0.0$ & $2.3 \pm 0.9$ & $40 \pm 13$ \\
\hline & & $100 \%$ & $17.2 \pm 1.4$ & $1.3 \pm 0.5$ & $0.1 \pm 0.1$ & $2.0 \pm 1.0$ & $40 \pm 13$ \\
\hline & & $140 \%$ & $15.7 \pm 1.3$ & $1.2 \pm 0.4$ & $0.1 \pm 0.1$ & $0.8 \pm 0.8$ & $7 \pm 7$ \\
\hline \multirow[t]{2}{*}{ ICRF } & & $50 \%$ & $23.2 \pm 1.5$ & $1.6 \pm 0.7$ & $0.2 \pm 0.2$ & $3.9 \pm 4.3$ & $73 \pm 12$ \\
\hline & & $100 \%$ & $32.2 \pm 2.3$ & $2.2 \pm 0.8$ & $1.9 \pm 0.6$ & $15.4 \pm 4.1$ & $93 \pm 7$ \\
\hline \multicolumn{8}{|l|}{ Significance $(P \leq \mathrm{F})$} \\
\hline AMF & & & $* * *$ & $* * *$ & $* * *$ & $* * *$ & $* * *$ \\
\hline Fertility & & & $* * *$ & $* * *$ & $* * *$ & $* * *$ & $* * *$ \\
\hline AMF $\times$ Fertility & & & $* *$ & NS & $* * *$ & $* * *$ & $* * *$ \\
\hline
\end{tabular}

${ }^{\mathrm{z}}$ See Table 1 for explanation of recommended fertility rates and comparative analysis.

y NonAMF $=$ noninoculated control.

VValues are means $\pm \mathrm{SE}, \mathrm{n}=15$.

wbased on percent of marketable (salable) plants.

NS, ${ }^{*}, * *, * * *$ Nonsignificant or significant at $P \leq 0.05,0.01,0.001$ respectively. 
and marketability occurred with BioterraPLUS plants at 50\% and $100 \%$ ICRF and MycorisePro at the 100\% ICRF rate. Plant growth increased with increasing fertility levels, however, plants at $140 \%$ OSRF (same Plevel as 100\% ICRF rate) had depressed growth compared to lower fertility levels. While AMF enhanced plant growth using OSRF at all concentrations, there was better growth and marketability with ICRF than OSRF in plants inoculated with AMF. While best overall treatments were with both commercial inocula (AMF) at the $100 \%$ of ICRF rate, the multi-isolate BioterraPLUS was generally better (greater root, shoot, and total plant DM) than the single isolate, MycorisePro (Table 2).

There were higher yields (shoot, root, leaf, and total plant DM, and leaf area) with the $100 \%$ ICRF rate, followed by the $50 \%$ ICRF and the $70 \%$ OSRF rate. These results are promising, in that under commercially recommended fertility levels, inoculation of $I$. carnea with commercial AMF had improved plant growth. When comparing AMF at the $50 \%$ and $100 \%$ inorganic SRF regime there was a mycorrhizal inoculation effect (MIE) of $220 \%$ and $168 \%$ increase, respectively, for BioterraPLUS, and a $112 \%$ and $110 \%$ increase, respectively, with MycorisePro compared to NonAMF plants (Table 2). The MIE level was very high, which is indicative of strong mycorrhizal dependence (Bagyaraj et al., 1988). While MycorisePro had a high MIE, highest MIE per respective fertilizer source and rate occurred with BioterraPLUS, which supports greater mycorrhizal dependency of I. carnea (based on plant growth enhancement).

Growth index and leaf area followed the same pattern observed for DM accumulation with higher values for AMF than NonAMF control plants (Table 2). There was an interaction $(P$ $\leq 0.001$ ) between AMF treatments and fertility for growth index and leaf area. The highest plant growth index of $\left(60,933 \mathrm{~cm}^{3}\right)$ was obtained in plants inoculated with AMF
BioterraPLUS under the 100\% ICRF recommend rate. Leaf area followed the same tendency with the greatest leaf area (968 $\mathrm{cm}^{2}$ ) in plants inoculated with BioterraPLUS at $100 \%$ ICRF rate and plants inoculated with MycorisePro $\left(894 \mathrm{~cm}^{2}\right)$ at the same fertility rate. AMF and fertility did not have an effect on specific leaf area, leaf area ratio, and root : shoot ratio (data not reported). While both AMF inocula enhanced growth at all OSRF levels, BioterraPLUS was generally more effective than MycorisePro at $100 \%$ OSRF rate.

There was an interaction $(P \leq 0.001)$ between AMF and fertility with number of leaves, flowers buds, and flowers at anthesis (blooms) (Table 3). Both AMF inocula enhanced plant growth with OSRF, however BioterraPLUS at $100 \%$ had greater leaf number than MycorisePro. Both commercial inocula at $100 \%$ ICRF rate had the greatest leaf and shoot DM, number of flower buds and flowers; however, flower number was highest with BioterraPLUS at the $100 \%$ ICRF (Table 3). AMF plants, independent of fertility, enhanced the number of leaves, flower buds and blooms. In general, the ICRF increased growth parameters more than the OSRF.

The overall improved plant growth of AMF plants was reflected in increased marketability of I. carnea. AMF had greater number of marketable plants among all fertility treatments than NonAMF plants (Table 3). The 140\% OSRF rate produced the lowest percentage of marketable plants among all treatments. While there were no differences in marketability between the NonAMF OSRF vs. ICRF, AMF plants with ICRF were more marketable than AMF with OSRF. BioterraPLUS at $100 \%$ and $50 \%$ ICRF, and MycorisePro at 100\% inorganic SRF rate had the greatest number of marketable plants.

LEAF CHLOROPHYLL CONTENT AND LEAF TISSUE ANALYSIS. Leaf chlorophyll content of container-grown I. carnea followed the same pattern observed for plant growth responses. Plants colo-

Table 4. Effect of mycorrhizal [(AMF) BioterraPLUS and MycorisePro], organic slow-release (OSRF) and inorganic controlled-release fertilizers (ICRF) on elemental concentration and total N, P, and $\mathrm{K}$ in leaf tissue of Ipomoea carnea.

\begin{tabular}{|c|c|c|c|c|c|c|c|c|}
\hline & & & Leaf & Elemental & Conen & Total leaf & Elemental & Content \\
\hline AMF & $\begin{array}{c}\text { Fertility } \\
\text { source }\end{array}$ & $\begin{array}{c}\text { Recommended } \\
\text { levely }\end{array}$ & $\begin{array}{c}\mathrm{N} \\
\left(\mathrm{g} \cdot \mathrm{kg}^{-1}\right)\end{array}$ & $\begin{array}{c}\mathrm{P} \\
\left(\mathrm{g} \cdot \mathrm{kg}^{-1}\right)\end{array}$ & $\begin{array}{c}\mathrm{K} \\
\left(\mathrm{g} \cdot \mathrm{kg}^{-1}\right)\end{array}$ & $\begin{array}{c}\mathrm{N} \\
(\mathrm{mg})\end{array}$ & $\begin{array}{c}\mathrm{P} \\
(\mathrm{mg})\end{array}$ & $\begin{array}{c}\mathrm{K} \\
(\mathrm{mg})\end{array}$ \\
\hline$\overline{\text { NonAMFz }^{2}}$ & OSRF & $70 \%$ & $21 \pm 1^{x}$ & $1.6 \pm 0.1$ & $19 \pm 1$ & $38 \pm 2$ & $3 \pm 0$ & $34 \pm 2$ \\
\hline & & $100 \%$ & $23 \pm 1$ & $1.8 \pm 0.1$ & $20 \pm 1$ & $58 \pm 3$ & $5 \pm 0.3$ & $50 \pm 3$ \\
\hline & & $140 \%$ & $21 \pm 1$ & $1.4 \pm 0.1$ & $20 \pm 1$ & $21 \pm 1$ & $2 \pm 0.2$ & $20 \pm 1$ \\
\hline & ICRF & $50 \%$ & $27 \pm 1$ & $2.3 \pm 0.1$ & $21 \pm 0$ & $46 \pm 2$ & $4 \pm 0.2$ & $38 \pm 0$ \\
\hline & & $100 \%$ & $32 \pm 1$ & $2.3 \pm 0.1$ & $24 \pm 0$ & $90 \pm 3$ & $6 \pm 0.3$ & $67 \pm 0$ \\
\hline BioterraPLUS & OSRF & $70 \%$ & $23 \pm 1$ & $1.8 \pm 0.1$ & $20 \pm 1$ & $58 \pm 3$ & $5 \pm 0.3$ & $50 \pm 3$ \\
\hline & & $100 \%$ & $24 \pm 1$ & $1.6 \pm 0.1$ & $22 \pm 1$ & $86 \pm 4$ & $6 \pm 0.4$ & $79 \pm 4$ \\
\hline & & $140 \%$ & $31 \pm 1$ & $2.1 \pm 0.1$ & $25 \pm 1$ & $68 \pm 2$ & $5 \pm 0.2$ & $55 \pm 2$ \\
\hline & ICRF & $50 \%$ & $33 \pm 1$ & $2.6 \pm 0.1$ & $29 \pm 0$ & $129 \pm 4$ & $10 \pm 0.4$ & $113 \pm 0$ \\
\hline & & $100 \%$ & $32 \pm 1$ & $2.5 \pm 0.1$ & $28 \pm 0$ & $179 \pm 6$ & $14 \pm 0.6$ & $157 \pm 0$ \\
\hline MycorisePro & OSRF & $70 \%$ & $21 \pm 1$ & $1.6 \pm 0.1$ & $18 \pm 1$ & $55 \pm 3$ & $4 \pm 0.3$ & $47 \pm 3$ \\
\hline & & $100 \%$ & $22 \pm 1$ & $1.6 \pm 0.1$ & $20 \pm 1$ & $110 \pm 5$ & $8 \pm 0.5$ & $100 \pm 5$ \\
\hline & & $140 \%$ & $25 \pm 1$ & $1.6 \pm 0.1$ & $18 \pm 1$ & $48 \pm 2$ & $3 \pm 0$ & $34 \pm 2$ \\
\hline & ICRF & $50 \%$ & $24 \pm 2$ & $2.1 \pm 0.1$ & $19 \pm 1$ & $67 \pm 6$ & $6 \pm 0$ & $53 \pm 3$ \\
\hline & & $100 \%$ & $36 \pm 1$ & $2.3 \pm 0.1$ & $25 \pm 0$ & $180 \pm 5$ & $12 \pm 0.5$ & $125 \pm 0$ \\
\hline Significance $(P$ & $\leq \mathrm{F})$ & & & & & & & \\
\hline $\mathrm{AMF}$ & & & $* * *$ & $* * *$ & $* * *$ & $* * *$ & $* * *$ & $* * *$ \\
\hline Fertility & & & $* * *$ & $* * *$ & $* * *$ & $* * *$ & $* * *$ & $* * *$ \\
\hline $\mathrm{AMF} \times$ fertil & & & $* * *$ & $*$ & $*$ & NS & NS & NS \\
\hline
\end{tabular}

${ }^{\mathrm{z} N o n A M F}=$ noninoculated control.

ySee Table 1 for explanation of recommended fertility rates and comparative analysis.

${ }^{x}$ Values are means $\pm \mathrm{SE}, \mathrm{n}=3$.

Ns, $*, * * * * *$ Nonsignificant or significant at $P \leq 0.05,0.01$, or 0.001 , respectively. 
nized with AMF (BioterraPLUS and MycorisePro) had greater chlorophyll content than NonAMF plants (Table 2). There was an interaction $(P \leq 0.001)$ between AMF and fertility treatments. Chlorophyll values ranged from 84 to $51 \mu \mathrm{g} \cdot \mathrm{cm}^{-2}$. Greatest leaf chlorophyll occurred with the highest rate of ICRF and OSRF, with the exception of AMF BioterraPLUS plants, which had lower chlorophyll at $140 \%$ OSRF. Plants fertilized with ICRF had greater leaf chlorophyll than OSRF plants. Results of chlorophyll analysis coincide with fertilizer levels used in the different fertility treatments. Leaf area and chlorophyll content vary according to mineral status $(\mathrm{N}, \mathrm{P}, \mathrm{K})$ of plants (Salisbury and Ross, 1992; Taiz and Zeiger, 1998). Increased leaf area and chlorophyll content of AMF colonized plants (Aguilera-Gomez et al., 1999; Estrada-Luna and Davies, 2003) were related to improved P uptake (Fitter, 1988).

Both AMF and fertility affected leaf mineral content (Table 4). In general, AMF plants with ICRF treatments had higher leaf N, P, and $\mathrm{K}$ than NonAMF with OSRF. There were interactions between AMF and fertility in leaf tissue macroelemental concentration for $\mathrm{N}(P \leq 0.001), \mathrm{P}(P \leq 0.05)$, and $\mathrm{K}(P \leq 0.05)$ (Table 4$)$. There were no AMF effects on other macro or microelements (data not reported).

Both $\mathrm{P}$ and $\mathrm{K}$ levels were equivalent between the $70 \%$ OSRF and $50 \%$ ICRF and the $140 \%$ OSRF and 100\% ICRF, however $\mathrm{N}$ was higher with the ICRF (Table 1). With NonAMF plants the $100 \%$ OSRF gave better growth responses than the 50\% ICRF. Conversely, when inoculated with AMF, the growth of the $50 \%$ ICRF treated plants was superior to $100 \%$ OSRF (Tables 2 and 3). Part of the dogma is that OSRF is more dependent on AMF and other associated soil microbes needed in the conversion of organic $\mathrm{N}$ and $\mathrm{P}$ sources to utilizable compounds in plant nutrient uptake than ICRF (Linderman and Davis, 2004). This was not the case with I. carnea where AMF + ICRF was more optimal than $\mathrm{AMF}+\mathrm{OSRF}$ or NonAMF + ICRF. The OSRF, Nitrell, requires the action of different microorganisms naturally present in the fertilized substrate media to slowly break down (mineralize) and release mineral nutrients in inorganic form, which can be taken up by plant roots. Hence, the presence of AMF in colonized plants in this experiment increased the availability and uptake of the OSRF. This was possibly a direct effect of increased mineralization rate of the OSRF, which may have been increased by the effective absorptive surface area of extraradical hyphae (Augé et al., 2003; Davies et al., 1992). Extraradical hyphae greatly increases the absorbing surface area of roots (George, 2000; Marschner, 1995; Smith and Read, 1997), and enhance the absorption of ions with low diffusion coefficient such as $\mathrm{P}, \mathrm{Cu}, \mathrm{Fe}$, and $\mathrm{Zn}$ (Marschner and Dell, 1994; Smith and Reed, 1997).

In another study with $G$. intraradicies comparing OSRF and ICRF, the release of nutrients from OSRF favored AMF establishment and function more than ICRF, unless overall P levels were low (Linderman and Davis, 2004). In that study, AMF proportionally enhanced growth of OSRF more than inorganic sources. However at the $1 \times(100 \%)$ recommended rate ICRF had greater growth than OSRF, regardless of AMF mycorrhizal treatment (Linderman and Davis, 2004). In our study, total colonization was comparable between the highest and lowest fertility levels, respectively, of ICRF and OSRF. Furthermore best plant growth responses and nutrient uptake, particularly $\mathrm{P}$, occurred with AMF and ICRF. Differences in results may also be attributed to the source and origin of AMF inocula, including multiple vs. single AMF species, differences in OSRF components, and host plant species response. There can be benefits in using multiple isolates compared to single AMF species (Davies et al., 2002; Koomen et al., 1987).

In our study, AMF + ICRF plants had the best growth and marketability, and exceeded that of AMF+ OSRF + or NonAMF + ICRF. While there were no differences in leaf $\mathrm{K}$, both leaf $\mathrm{N}$ and $\mathrm{P}$ were higher in NonAMF at 50\% ICRF than 100\% OSRF; (total fertilizer $\mathrm{N}$ was the same and $\mathrm{P}$ and $\mathrm{K}$ were higher in the $100 \%$ organic SRF). When inoculated with BioterraPlus, 50\% ICRF had greater leaf N, P, and K than $100 \%$ OSRF, while $50 \%$ ICRF MycorisePro had comparable leaf N, P, and K to NonAMF 100\% OSRF (Table 4).

The lower, plant-available source of $\mathrm{P}$ in the OSRF [Nitrell 5-3-4 (5N-1.3P-3.3K)] is crushed bone meal, fish meal, feather meal, peanut meal, chicken manure, and rock phosphate. The more soluble $\mathrm{P}$ sources of ammonium phosphate and calcium phosphate are in the ICRF [Osmocote 18-7-10 (18N-3.0P-8.3K)] (Table 1). The $140 \%$ OSRF depressed growth compared to other SRF sources and concentrations, suggesting too high a fertility level and a build-up of soluble salts. However, differences in soluble salts were not detected since the leachate EC of the $140 \%$ OSRF was not statistically higher than other treatments (data not presented). Another factor could have been the high container media temperatures [average maximum $44.8^{\circ} \mathrm{C}\left(113^{\circ} \mathrm{F}\right)$ during the course of this study]. High container media temperatures are a routine problem in container production systems in Texas and the southern United States (Newman and Davies, 1988b). High temperatures can stress plants and lead to greater susceptibility to pathogens and pests. High temperatures also depress microbial populations needed for nitrification and the conversion of $\mathrm{P}$ from rock phosphate and bone meal to a more utilizable form (Sylvia et al. 1999). Ammonia toxicity can also occur because of high temperature suppression of microbial activity needed during nitrification. Conversely, high temperature can speed up the release of nutrients from resin coated ICRF, in part because of temperature-induced changes in permeability of the prill wall of the ICRF. Organic P in the OSRF are mineralized into an inorganic $\mathrm{P}$ form that can be taken up by plant roots. In another study (Amaya-Carpio, 2002; Amaya-Carpio et al., 2003), root acid phosphatase activity increased with AMF colonization causing conversion of organic to inorganic P. Phosphatase is the primary enzyme responsible for the mineralization of organic $\mathrm{P}$. Consequently, this lead to greater $\mathrm{P}$ uptake, plant growth, and photosynthetic rates.

In general, enhanced nutrition of AMF plants resulted in a larger plant biomass. AMF colonization enhances the availability and uptake of both macro and micronutrients (Davies et al., 2000; Smith and Reed, 1997). The significance of AMF on growth enhancement observed in this experiment may have been the result of increased levels in $\mathrm{N}, \mathrm{P}$, and $\mathrm{K}$ promoted by AMF symbiosis. Independent of fertilization, AMF colonization was able to enhance the growth and nutrition status of I. carnea. In general $50 \%$ and $100 \%$ ICRF and $100 \%$ OSRF had the best growth rates. MycorisePro at $100 \%$ inorganic SRF and BioterraPlus at $50 \%$ and $100 \%$ SRF plants had the highest concentrations of $\mathrm{N}$, $\mathrm{P}$ and $\mathrm{K}$ and total content $(\mathrm{mg})$ of these ions in part because of greater plant biomass (Table 4). Hence, the influence of AMF on nutrient uptake of $\mathrm{N}, \mathrm{P}, \mathrm{K}$ was dependent on fertilization regime and AMF species colonizing the roots.

While we did not measure plant gas exchange, in other mycorrhizal studies there was a correlation between increased plant nutrient levels, particularly $\mathrm{P}$, and increased photosynthesis and plant DM yield (Aguilera-Gomez et al., 1999). There is also a 
strong relationship between photosynthesis and nitrogen availability since the photosynthetic machinery (i.e., Rubsico) accounts for more than half of the $\mathrm{N}$ in leaves (Lambers et al., 1998). In our experiment, the higher chlorophyll content and high $\mathrm{N}$ leaf concentration found in AMF plants with ICRF at the 100\% recommended rate, suggests that higher photosynthesis rates occurred, resulting in greater growth and number of marketable plants than other treatments. In another study (Amaya-Carpio et al., 2003), AMF increased photosynthesis and growth of $I$. carnea with an OSRF.

\section{Arbuscular mycorrhizal fungal colonization}

At the end of the experiment the plants inoculated with commercial AMF had $14 \%$ to $26 \%$ total root colonization, while NonAMF roots remained noncolonized except for one slightly infected (1\%) container plant at the $70 \%$ OSRF recommend rate (Table 5). Mean colonization levels for BioterraPLUS and MycorisePro inoculated plants were, respectively, $22 \%$ and $17 \%$. There was a significant $(P \leq 0.05)$ interaction between AMF and fertility for percentage of hyphae, vesicle, and total colonization. Total colonization with AMF was highly correlated with intraradical hyphae $\left(r^{2}=1.00\right)$ and vesicle development $\left(r^{2}=0.78\right)$.

While greater colonization $(26.2 \%)$ was observed in plants inoculated with the BioterraPLUS at $140 \%$ OSRF rate, this was statistically the same colonization level as the $50 \%$ and $100 \%$ ICRF treatments. Colonization was slightly less in MycorisePro than BioterraPLUS treatments at $140 \%$ organic SRF and $50 \%$ and $100 \%$ inorganic SRF. Nonetheless, colonization was higher than reported in a commercial nursery study using the same MycorisePro isolate of Glomus intraradicies (Davies et al., 2000), or in a drought stress study with pepper colonized with $G$. deserticola (Davies et al, 1992). In the former nursery study, similar growth enhancement occurred in AMF inoculated Nandina domestica, which only had $10 \%$ total root length colonization. That study was done in a commercial nursery site with ICRF levels of 4.2 $\mathrm{kg} \cdot \mathrm{m}^{-3}$ of Osmocote $24-4-8(24 \mathrm{~N}-1.7 \mathrm{P}-6.6 \mathrm{~K})$

Differences in colonization rates and plant growth may be due in part to the composite AMF species mix, compared to a single species inocula. BioterraPLUS is a composite mix of seven mycorrhizal isolates including Gigaspora and Glomus species; the inoculation rate was $30 \mathrm{~mL}$ with a range of 1500 to 1800 spores per plant. The MycorisePro inoculum was composed of a single isolate, Glomus intraradices. The inoculation rate was $45 \mathrm{~mL}$ with an estimated range of 45 to 315 propagules per plant. Because of the use of single and mixed species isolates and the estimate of most probable numbers (MPN), which included spores and vegetative mycelium, it was not feasible to have an exact equal propagules number among AMF inocula. However, in all cases the inoculum levels used met or exceeded the manufacturer's recommended rate.

Other factors affecting colonization levels and growth responses include the origin (ecotypes) of the commercial AMF. The single isolate of MycorisePro was selected from Canada, whereas species in the BioterraPLUSinocula have a wider origin, composed of isolates from southwestern U.S. desert regions as well as more mesic locations from the northwestern United States. Nonetheless, plants inoculated with MycorisePro in the current study did better than NonAMF plants and the same isolate was used successfully in a commercial Texas container production nursery (Davies et al., 2000).

Considering the high average air and container root ball temperatures (average maximum container temperatures were 44.8 ${ }^{\circ} \mathrm{C}$ ), plant growth and colonization levels were exceptional. AMF are known to enhance nursery crop resistance to high temperatures (Newman and Davies, 1988a, 1988b). Nonetheless, reasonable

Table 5. Effect of mycorrhizal [(AMF) BioterraPLUS and MycorisePro], organic slow-release (OSRF) and inorganic controlled-release fertilizers (ICRF) on hyphae, vesicles, and total root length colonization with AMF of container-grown Ipomoea carnea.

\begin{tabular}{|c|c|c|c|c|c|}
\hline $\mathrm{AMF}$ & $\begin{array}{c}\text { Fertility } \\
\text { source }\end{array}$ & $\begin{array}{c}\text { Recommended } \\
\text { rates }^{z}\end{array}$ & $\begin{array}{c}\text { Hyphae } \\
(\%)\end{array}$ & $\begin{array}{l}\text { Vesicle } \\
(\%)\end{array}$ & $\begin{array}{c}\text { Total } \\
\text { colonization } \\
(\%)\end{array}$ \\
\hline \multirow[t]{5}{*}{ NonAMFy } & OSRF & $70 \%$ & $1 \pm 0^{x}$ & $1 \pm 0$ & $1 \pm 0$ \\
\hline & & $100 \%$ & $0 \pm 0$ & $0 \pm 0$ & $0 \pm 0$ \\
\hline & & $140 \%$ & $0 \pm 0$ & $0 \pm 0$ & $0 \pm 0$ \\
\hline & ICRF & $50 \%$ & $0 \pm 0$ & $0 \pm 0$ & $0 \pm 0$ \\
\hline & & $100 \%$ & $0 \pm 0$ & $0 \pm 0$ & $0 \pm 0$ \\
\hline \multirow[t]{5}{*}{ BioterraPLUS } & OSRF & $70 \%$ & $18 \pm 0$ & $8 \pm 1$ & $18 \pm 1$ \\
\hline & & $100 \%$ & $19 \pm 0$ & $4 \pm 0$ & $19 \pm 0$ \\
\hline & & $140 \%$ & $26 \pm 2$ & $16 \pm 2$ & $26 \pm 2$ \\
\hline & ICRF & $50 \%$ & $23 \pm 1$ & $14 \pm 1$ & $23 \pm 1$ \\
\hline & & $100 \%$ & $22 \pm 1$ & $8 \pm 1$ & $22 \pm 1$ \\
\hline \multirow[t]{5}{*}{ MycorisePro } & OSRF & $70 \%$ & $19 \pm 1$ & $10 \pm 1$ & $21 \pm 1$ \\
\hline & & $100 \%$ & $19 \pm 1$ & $10 \pm 1$ & $19 \pm 1$ \\
\hline & & $140 \%$ & $12 \pm 0$ & $4 \pm 0$ & $13 \pm 0$ \\
\hline & ICRF & $50 \%$ & $18 \pm 0$ & $6 \pm 1$ & $19 \pm 1$ \\
\hline & & $100 \%$ & $14 \pm 1$ & $2 \pm 0$ & $14 \pm 1$ \\
\hline \multicolumn{6}{|l|}{ Significance $(P \leq \mathrm{F})$} \\
\hline AMF & & & $* * *$ & $* * *$ & $* * *$ \\
\hline Fertilizer & & & NS & NS & NS \\
\hline Fertilizer $\times$ AMF & & & $*$ & $* *$ & $*$ \\
\hline
\end{tabular}

${ }^{2}$ See Table 1 for explanation of recommended fertility rates and comparative analysis.

yNonAMF $=$ noninoculated control.

${ }^{x}$ Values are means $\pm \mathrm{SE}, \mathrm{n}=5$; total observations per treatment $=750$.

NS, ${ }^{*}, * * * * *$ Nonsignificant or significant at $P \leq 0.05,0.01$, or 0.001 , respectively. 

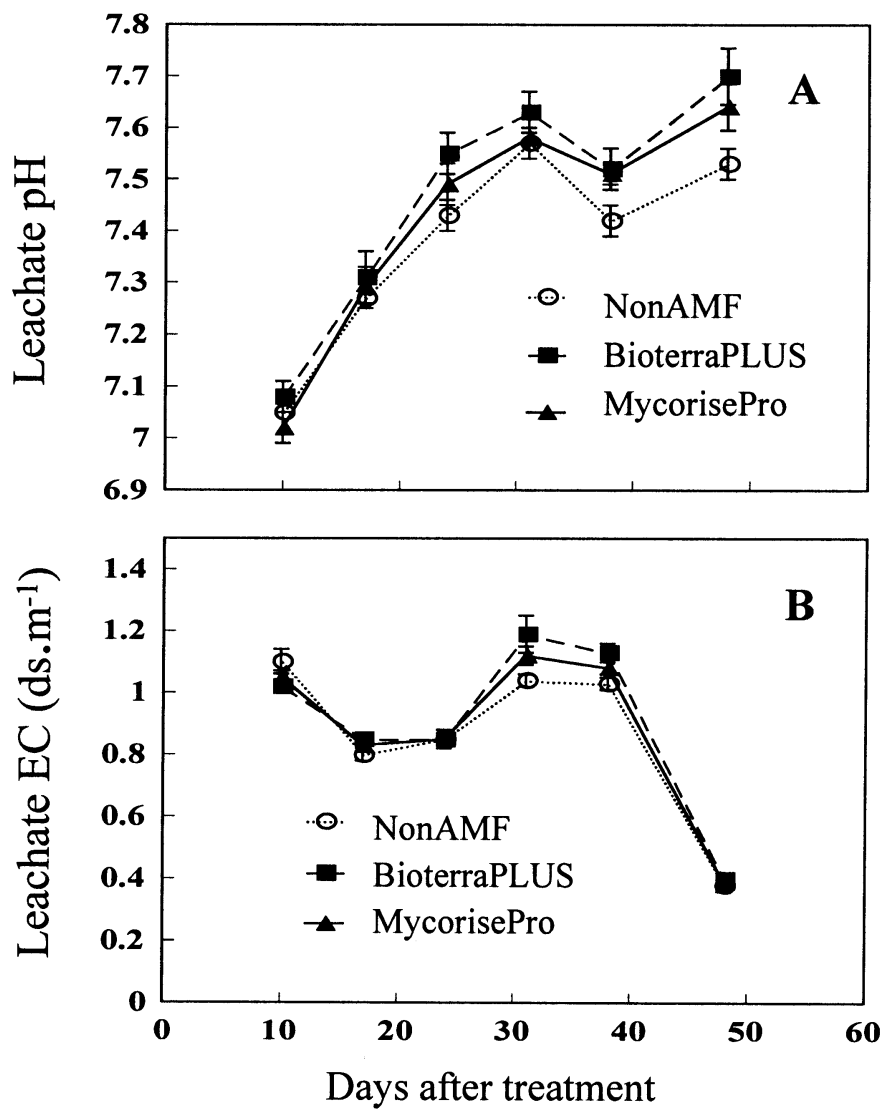

Fig. 1. Effect of arbuscular mycorrhizal fungi (AMF) over a 50-d sampling period on: (A) leachate $\mathrm{pH}$ and (B) electrical conductivity (EC) of container-grown Ipomoea carnea. All fertilizer sources and rates were pooled for a given AMF treatment $(n=45 ; \pm S E)$. Bars indicate the standard error of the mean $( \pm \operatorname{SE})$; treatment effects of AMF, fertility source and time duration (T) were highly significant $(P \leq 0.001)$ for $\mathrm{pH}$ and EC. NonAMF = noninoculated control; commercial AMF inocula were BioterraPLUS and MycorisePro.

total colonization levels occurred even with the $140 \%$ OSRF, particularly when inoculated with BioterraPlus (26\%) (Table 5). AMF effects can still occur with low colonization. However, colonization levels are not always good predictors of growth enhancement or nutrient uptake in response to AMF inoculation (Newman and Davies, 1988a). Niemira et al. (1995) reported beneficial growth responses at very low colonization levels $(0.4 \%)$ of $G$. intraradices in a greenhouse study with mini-tuber potato (Solanum tuberosum L.). In a commercial nursery production study in Texas, Davies et al. (2000) reported growth enhancement in AMF inoculated Nandina domestica, which only had $10 \%$ total colonization with the mycorrhizal fungus Glomus intraradices.

\section{Analysis of $\mathrm{pH}$ and electrical conductivity (EC) of container leachate}

The effect of time (days) after treatments on $\mathrm{pH}$ leachate of the containerized crop was significant $(P \leq 0.001)$ as an independent factor. The $\mathrm{pH}$ of the water runoff increased over time, largely due to the alkalinity of the irrigation water $(\mathrm{pH} \mathrm{8.0)}$ and the reduction of fertility charge over the course of the experiment (Fig. 1.). While the irrigation water was treated with sulfuric acid to reduce the $\mathrm{pH}$, insufficient acid was injected and consequently the adjusted $\mathrm{pH}$ of 6.5 was not obtained. The lower $\mathrm{pH}$ in leachate at the first evaluation (day 10) may be an indication of a high release of nutrients from OSRF and ICRF since these fertilizers are acidic in nature (Davidson et al., 2000). There were no differences in $\mathrm{pH}$ between OSRF and ICRF.

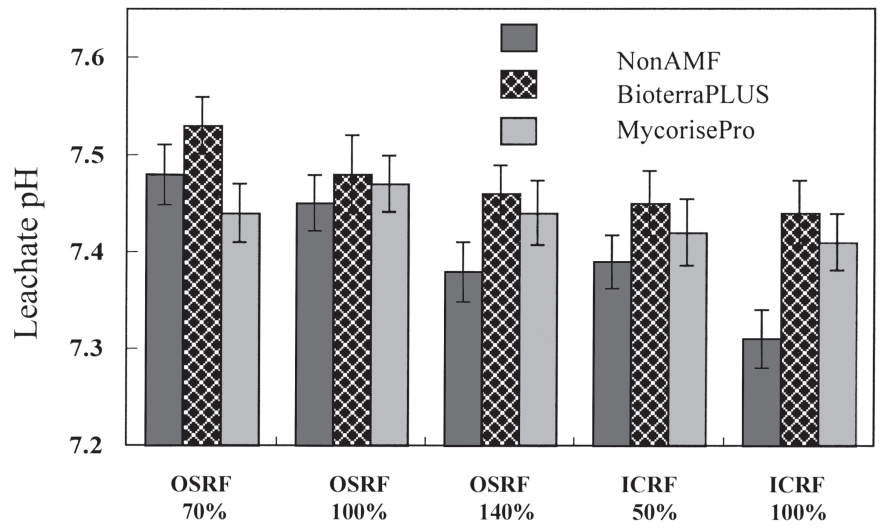

Recommended rates of organic and inorganic slow release fertilizer

Fig. 2. Effect of arbuscular mycorrhizal fungi (AMF) on leachate $\mathrm{pH}$ of containergrown Ipomoea carnea. Samples were taken at $50 \mathrm{~d}$, prior to harvesting the experiment. Organic slow release (OSRF) and inorganic controlled-release fertilizers (ICRF) were applied as percentage of recommended rates $(n=15$; $\pm \mathrm{SE})$. Bars indicate the standard error of the mean $( \pm \mathrm{SE})$; treatment effects of AMF and fertility $(\mathrm{F})$ were highly significant $(P \leq 0.001)$ and the interaction of $\mathrm{AMF} \times \mathrm{F}$ was significant $(P \leq 0.05)$. NonAMF $=$ noninoculated control. Commercial AMF were BioterraPLUS and MycorisePro.

There was an effect $(P \leq 0.05)$ due to AMF and fertility interaction in the runoff $\mathrm{pH}$ (Figs. 1 and 2). The leachate from AMF plants had higher $\mathrm{pH}$ than NonAMF, at the highest OSRF and ICRF rates (Fig. 2). AMF plants generally had a higher nutritional status than similar fertility-treated NonAMF plants. The overall increase over time in leachate $\mathrm{pH}$ with the same substrate (3 pine bark : 1 sand, $v / v$ ) was reported in a nonmycorrhizal study at the nursery site utilizing the same water source (Goyne, 1998). Even though there was a statistical difference in leachate $\mathrm{pH}$ between NonAMF and AMF plants (7.6 vs. 7.7), these small differences in $\mathrm{pH}$ had minimal physiological and metabolic effect on I. carnea.

The release of nutrients over time as determined by EC leachate readings was highest during the beginning of the growth period (day 10) and at days 31 and 38 (Fig. 1). The lowest EC value were detected at the final sample day (day 48) in all the treatments, independent of AMF treatment, which was indicative of decreased residual fertility charge over time (Fig. 1). There was an interaction of fertility and time (days after treatment) on leachate EC. In general, AMF had no significant effect on EC.

In summary, the two commercial AMF inocula enhanced growth, leaf nutrition and marketability of I. carnea with ICRF and OSRF under high container production temperatures. BioterraPlus was slightly more effective that MycorisePro. Similar results were reported by Koomen et al. (1987) who concluded that a mixed (multiple-species) AMF inocula was more effective that a single AMF species in promoting plant growth of Trifolium repens L. (clover) and Fragaria vesca L. (strawberry). Plants inoculated with AMF at the recommended rate (100\%) of ICRF had the best growth response. This research contradicts dogma that AMF are more beneficial when used with an OSRF than ISRF. This work is of particular importance to commercial nurseries and greenhouse production since ICRF are much more commonly used than OSRF. AMF plants at the 50\% ICRF generally had better growth, nutrient uptake and marketability than the $100 \%$ and $150 \%$ OSRF; BioterraPlus plants at the 50\% ICRF had greater growth than NonAMF at 100\% ICRF. Hence, lower fertilization for AMF plants could minimize leaching and runoff of fertilizer leachate. While AMF had little effect on $\mathrm{pH}$ or EC leachates, 
AMF plants were larger than NonAMF plants and subsequently absorbed a greater total amount of ions, which could potentially minimize leaching and runoff of fertilizer nutrients.

\section{Literature Cited}

Aguilera-Gomez, L., F.T. Davies, Jr., V. Olalde-Portugal, S.A. Duray, and L. Phavaphutanon. 1999. Influence of phosphorus and endomycorrhiza on gas exchange, plant growth and mycorrhizal development of chile ancho pepper (Capsicum annuum L. cv. San Luis). Photosynthetica 36(3):441-449.

Amaya-Carpio, L. 2002. Effects of arbuscular mycorrhizal fungi on growth, physiology and irrigation run-off of selected ornamental crops. PhD Diss. Texas A\&M Univ., College Station.

Amaya-Carpio, L., F.T. Davies, Jr., T. Fox, A. Cartmill, M.A. Arnold, and C.J.He. 2003. Effect of arbuscular mycorrhizal fungi and organic fertilizer on photosynthesis, growth, nutrient uptake and root phosphatase activity of Ipomoea carnea subsp. fistulosa. HortScience 38:810.

Arnold, M.A. and H.J. Lang. 1996. Greenhouse and subsequent landscape growth responses of petunia and pansy to container size, copper-coated containers and extended production times. J. Subtropical Plant Sci. 48:49-56.

Augé, R.M. 2001. Water relations, drought and vesicular-arbuscular mycorrhizal symbiosis. Mycorrhiza 11:3-42.

Augé, R.M., J.L. Moore, K. Cho, J.C. Stutz, D.M. Sylvia, A.K. Al-Agely, and A.M. Saxton. 2003. Relating foliar dehydration tolerance of mycorrhizal Phaseolus vulgaris to soil and root colonization by hyphae. J. Plant Physiol. 160:1147-1156.

Bagyaraj, F.J., A. Manjunath, Y.S. and Govinda. 1988. Mycorrhizal inoculation effect on different crops. J. Soil Biol. Ecol. 8:98-103.

Biermann, B. and R.G. Linderman. 1981. Quantifying vesicular-arbuscular mycorrhizae: A proposed method towards standardization. New Phytol. 87:63-67.

Biermann, B. and R.G. Linderman. 1983. Increased geranium growth using preplant inoculation with a mycorrhizal fungus. J. Amer. Soc. Hort. Sci. 108:972-976.

Cabrera, R. 1997. Comparative evaluation of nitrogen release patterns for controlled-release fertilizers by nitrogen leaching analysis. HortScience 32:669-673.

Davies, F.T., Jr. 2000. Benefits and opportunities with mycorrhizal fungi in nursery propagation and production systems. Combined Proc. Intl. Plant Prop. Soc. 50:482-489.

Davies, F.T., Jr., V. Olalde-Portugal, L. Aguilera-Gomez, M.J. Alvarado, R.C. Ferrera-Cerrato, and T.W. Boutton. 2002. Alleviation of drought stress of chile ancho pepper (Capsicum annuum L. cv. San Luis) with arbuscular mycorrhiza indigenous to Mexico. Scientia Hort. 92:347-359.

Davies, F.T., J.R. Potter, and R.G. Linderman. 1992. Mycorrhiza and repeated drought exposure affect drought resistance and extratradical hyphae development of pepper plants independent of plant size and nutrient content. J. Plant Physiol. 139:289-294.

Davies, F.T., J.R. Potter, and R.G. Linderman. 1993. Drought resistance of mycorrhizal pepper plants independent of leaf Pconcentration-Time course response of gas exchange and water relations. Physiol. Plant. $87: 45-53$.

Davies, F.T., Jr., J.A. Saraiva Grossi, L. Carpio, and A.A. Estrada-Luna. 2000. Colonization and growth effects of the mycorrhizal fungus Glomus intraradicies in a commercial nursery container production system. J. Environ. Hort. 18:247-251.

Davidson, H.R., R. Mecklenburg, and C. Peterson. 2000. Nursery management administration and culture. 4 th ed. Prentice Hall, Englewood Cliffs, N.J.

Estrada-Luna, A.A. and F.T. Davies, Jr. 2003. Arbuscular mycorrhizal fungi influence water relations, gas exchange, abscisic acid and growth of micropropagated chile ancho pepper (Capsicum annuum L. cv. San Luis) plantlets during acclimatization and post-acclimatization. J. Plant Physiol. 160:1073-1083.
Fitter, A.H. 1988. Water relations of red clover Trifolium pratens L. as affected by VA mycorrhizal infection and phosphorus supply before and during drought. J. Expt. Bot. 202:595-603

George, E. 2000. Nutrient uptake, p. 288-307. In: Y. Kapulnik and D.D. Douds, Jr. (eds.). Arbuscular mycorrhizas: Physiology and function. Kluwer Academic Publishers, Netherlands.

Goyne, M.W. 1998. Effects of alternative container media components on the growth of selected under-utilized small ornamental trees. M.S. Thesis. Dept. of Horticultural Science, Texas A\&M Univ., College Station.

Koske, R.W. and J.N. Gemma. 1989. A modified procedure for staining roots to detect VA mycorrhizas. Mycorrhizal Res. 92:486-505.

Koomen, I., C. Grace, and D. S. Hayman. 1987. Effectiveness of single and multiple mycorrhizal inocula on growth of clover and strawberry plants at two soil pHs. Soil Biol. Biochem. 195:539-544.

Lambers, H., F.S. Chapin, and T.L. Pons. 1998. Plant physiological ecology. Springer-Verlag, Berlin.

Lea-Cox, J.D. and D.S. Ross. 2001. Water and nutrient management planning-Monitoring of irrigation and fertilization practices. Combined Proc. Intl. Plant Prop. Soc. 51:575-580.

Linderman, R.G. 1986. Managing rhizosphere microorganisms in the production of horticultural crops. HortScience 21:1299-1306.

Linderman, R.G. and E.A. Davis. 2004. Evaluation of commercial inorganic and organic fertilizer effects on arbuscular mycorrhizae formed by Glomus intraradices. HortTechology 14:196-202.

Marschner, H. 1995. Mineral nutrition of higher plants. Academic, London.

Marschner, H. and B. Dell. 1994. Nutrient uptake in mycorrhizal symbiosis. Plant Soil 159:89-102.

Moran, R. 1982. Formulae for determination of chlorophyllous pigments extracted with $N, N$-Dimethylformamide. Plant Physiol. 69:1376-1381.

Newman, S.E. and F.T. Davies, Jr. 1988a. High root-zone temperatures, mycorrhizal fungi, and water relations and root hydraulic conductivity of selected container grown woody plants. J. Amer. Soc. Hort. Sci. 113:138-145.

Newman, S.E. and F.T. Davies, Jr. 1988b. Influence of field bed position, ground surface color, mycorrhizal fungi and high root-zone temperature in woody plant container production. Plant Soil 112:29-35.

Niemira, B.B., G.R. Safir, and G.W. Bird. 1995. Production of prenuclear minitubers of potato with peat-based arbuscular mycorrhizal fungal inoculum. Agron. J. 87:942-946.

Salisbury F.B. and C.W. Ross. 1992. Plant physiology. $4^{\text {th }}$ ed. Wadswordth, Belmont, Calif.

SAS Institute. 2000. SAS/stats user's guide. version 8. SAS Inst., Cary, N.C.

Smith, S.E. and D.J. Read. 1997. Mycorrhizal symbiosis. $2^{\text {nd }}$ ed. Academic, London.

Sylvia, D., A. Alagely, D. Kent, and R. Mecklenburg. 1998. Mycorrhiza of landscape trees produced in raised beds and containers. J. Arboricult. 24:308-314.

Sylvia, D.M., J.J. Fuhrman, P.G. Hartel, and D.A. Zuberer. 1999. Principles and applications of soil microbiology. $2^{\text {nd }}$ ed. Prentice-Hall, Englewood Cliffs, N.J.

Taiz, L. and E. Zeiger. 1998. Plant physiology. $2^{\text {nd }}$ ed. Sinauer, Sunderland, Mass.

Varma, A. and H. Schuepp. 1996. Influence of mycorrhization on the growth of micropropagated plants, p. 113-132. In: K.G. Mukerji (ed.). Concepts in mycorrhizal research. Kluwer, Netherlands.

Wright, R.D. 1986. The pour-through nutrient extraction procedure. HortScience 21:227-229.

Yadava, U.L. 1986. A rapid and nondestructive method to determine chlorophyll in intact leaves. HortScience 21:1449-1450.

Yeager, T., C. Gilliam, T. Bilderback, D. Fare, A. Niermiera, and K. Tilt. 1997. Best management practices-guide for producing container-grown plants. Southern Nursery Assn., Atlanta, Ga. 